\title{
Pulsed radiofrequency treatment in interventional pain management: mechanisms and potential indications - a review
}

\author{
Nicholas H. L. Chua $\cdot$ Kris C. Vissers • \\ Menno E. Sluijter
}

Received: 9 July 2010 /Accepted: 12 November 2010 / Published online: 30 November 2010

(C) The Author(s) 2010. This article is published with open access at Springerlink.com

\begin{abstract}
Background The objective of this review is to evaluate the efficacy of Pulsed Radiofrequency (PRF) treatment in chronic pain management in randomized clinical trials (RCTs) and well-designed observational studies. The physics, mechanisms of action, and biological effects are discussed to provide the scientific basis for this promising modality.

Methods We systematically searched for clinical studies on PRF. We searched the MEDLINE (PubMed) and EMBASE database, using the free text terms: pulsed radiofrequency, radio frequency, radiation, isothermal radiofrequency, and combination of these. We classified the information in two tables, one focusing only on RCTs, and another, containing prospective studies. Date of last electronic search was 30 May 2010. The methodological quality of the presented reports was scored using the original criteria proposed by Jadad et al. Findings We found six RCTs that evaluated the efficacy of PRF, one against corticosteroid injection, one against sham intervention, and the rest against conventional RF thermocoagulation. Two trials were conducted in patients with
\end{abstract}

N. H. L. Chua $(\bowtie)$

Department of Anaesthesiology, Tan Tock Seng Hospital,

11 Jalan Tan Tock Seng,

Singapore, Singapore 308433

e-mail: nicholaschua143@gmail.com

N. H. L. Chua $\cdot$ K. C. Vissers

Department of Anesthesiology, Pain and Palliative Care,

Radboud University Nijmegen Medical Centre,

Nijmegen, The Netherlands

M. E. Sluijter

Institute for Anesthesiology and Pain, Swiss Paraplegic Center,

Nottwil, Switzerland lower back pain due to lumbar zygapophyseal joint pain, one in cervical radicular pain, one in lumbosacral radicular pain, one in trigeminal neuralgia, and another in chronic shoulder pain.

Conclusion From the available evidence, the use of PRF to the dorsal root ganglion in cervical radicular pain is compelling. With regards to its lumbosacral counterpart, the use of PRF cannot be similarly advocated in view of the methodological quality of the included study. PRF application to the supracapular nerve was found to be as efficacious as intra-articular corticosteroid in patients with chronic shoulder pain. The use of PRF in lumbar facet arthropathy and trigeminal neuralgia was found to be less effective than conventional RF thermocoagulation techniques.

Keywords Pulsed radiofrequency · Neuromodulatory treatment $\cdot$ Non-ablative pain treatment $\cdot$ Radiofrequency treatment $\cdot$ Chronic pain management $\cdot$ Interventional pain treatment

\section{Introduction}

The idea of Pulsed Radiofrequency (PRF) was spawned after a chance meeting in 1993, and the first PRF procedure - on a lumbar dorsal root ganglion, took place on February 1, 1996 [13, 51, 53]. Since then, there had been reports that it has been successfully used for the treatment of myriad pain conditions, including cervical radicular pain, facial pain including trigeminal neuralgia (TN), sacroiliac joint pain, facet arthropathy, shoulder pain, postsurgical pain, radicular pain, groin pain, and myofascial pain conditions [9]. 
The rationale behind the development of PRF was essentially to expand the treatment possibilities that serve the interest of the patient [53]. In general, there are two types of PRF procedures. The first category is formed by those procedures, where continuous radiofrequency (RF) has provided us with a satisfactory method, such as the thermocoagulation of the medial branch. In this category, the potential contribution of PRF would probably be modest at best. Even if PRF is equally effective as thermal or conventional RF in this category; the impetus to adopt PRF would lie in a significant reduction in complications or side effects. The second type of procedure is where continuous RF has limited indications. This includes PRF treatment for peripheral neuropathies, arthrogenic pain, painful trigger points, and PRF application of the dorsal root ganglion in patients with neuropathy or radiculopathy [56].

Research involving the physics, mechanisms of action, and relevant biological effects of PRF have lagged behind its use in clinical practice. In spite of this, there are a total of six reviews on PRF procedures for chronic pain management [1, $5,6,8,23,35]$, and another three reviews on RF with specific mention on PRF modalities at the time of writing this manuscript $[36,44,61]$. An additional two reviews on interventional pain management techniques in general also discuss PRF $[12,48]$. All these agree that the evidence on PRF is accumulating. The objective of this review is, therefore, to explain the physical, as well as the biologic effects of PRF and to evaluate the efficacy PRF therapy in chronic pain management, firstly in randomized clinical trials (RCTs), and then, in well-designed observational studies.

\section{Mechanism of action}

The mechanism of action of PRF is currently undergoing extensive research. At the moment, most studies point towards an alteration in synaptic transmission, in a neuromodulatory-type effect $[7,8]$. There is, however, an ongoing discussion on whether or not the effect of PRF is minimally ablative. Considering the physical events around the electrode, even if a certain level of destruction does occur during PRF, the degree of clinical relevance is questionable as PRF has demonstrated a remarkable margin of safety.

\section{Physics}

Biological changes in tissues during PRF can occur due to the thermal effects, the high intensity electric fields, or as a result of both. PRF applies short pulses of RF signals from an RF generator to the neural tissue. The production of heat during these pulses depends on the power deposition. For the RF frequency of $420 \mathrm{kHz}$, the power deposition, $P$ is:

$P=\frac{0.5(j)^{2}}{\sigma}$

In other words:

Power deposition $\alpha \frac{\text { Voltage applied }^{2} \times \text { Exposure time }}{\text { Tissue resistivity }^{-}}$

Commercially available RF generators provide PRF signals with pulse durations ranging from 5 to $50 \mathrm{~ms}$ and pulse frequency ranging from 1 to $10 \mathrm{~Hz}$, but the most commonly used sequence is a pulse frequency of $2 \mathrm{~Hz}$ and a pulse width of $20 \mathrm{~ms}$ (Fig. 1) [50]. The intrinsic radiofrequency oscillation frequency within each pulse is still about $420 \mathrm{kHz}$, which is the same as for RF. In PRF, because the pulse duration is only a small percentage of the time between pulses, the average tissue temperature rise for the same RF voltage is much less for PRF than for RF. For instance, using a sequence of $2 \mathrm{~Hz} \times 20 \mathrm{~ms}$, the power deposition is $4 / 100$ of that during continuous RF for the same voltage. For this reason, higher voltages can be applied to the electrode in PRF than are commonly used in $\mathrm{RF}$ without raising the average tissue temperature near the electrode into the denaturation range above $45^{\circ} \mathrm{C}$. PRF was initially thought to have no elevated thermal effects, but in vitro experiments have demonstrated the occurrence of brief elevations of temperature-"heat spikes" around the needle tip to about $45^{\circ} \mathrm{C}-50^{\circ} \mathrm{C}$, depending on the tissue impedance [14]. The magnitude of such spikes has also been shown to reduce significantly with a decrease in the pulse width, for example from 20 to $10 \mathrm{~ms}$ [14]. It is, however, not known if these transient "heat spikes" have an ablative effect.

Notwithstanding the uncertainty regarding the extent of the thermal effects, the effects of the high-intensity electric fields have been well established. In general, PRF can produce far stronger electrical fields than RF. Just ahead of the electrode tip, the field is as high as $185,000 \mathrm{~V} / \mathrm{m}$ for an applied voltage of $45 \mathrm{~V}$. However, as the electric fields wane rapidly with increasing distance from the tip, there is very little destruction that results. In fact, at just $0.5 \mathrm{~mm}$ away from the tip, the electric field strength falls exponentially to just a fraction of its initial magnitude [14]. Majority of the target tissues are thus subjected to low or moderate-strength electric fields, which may, in fact, play an important role in the mode of action of PRF.

Electric fields can have plausibly significant effects on cells because of the transmembrane potentials $\left(\mathrm{U}_{\mathrm{m}}\right)$ that 


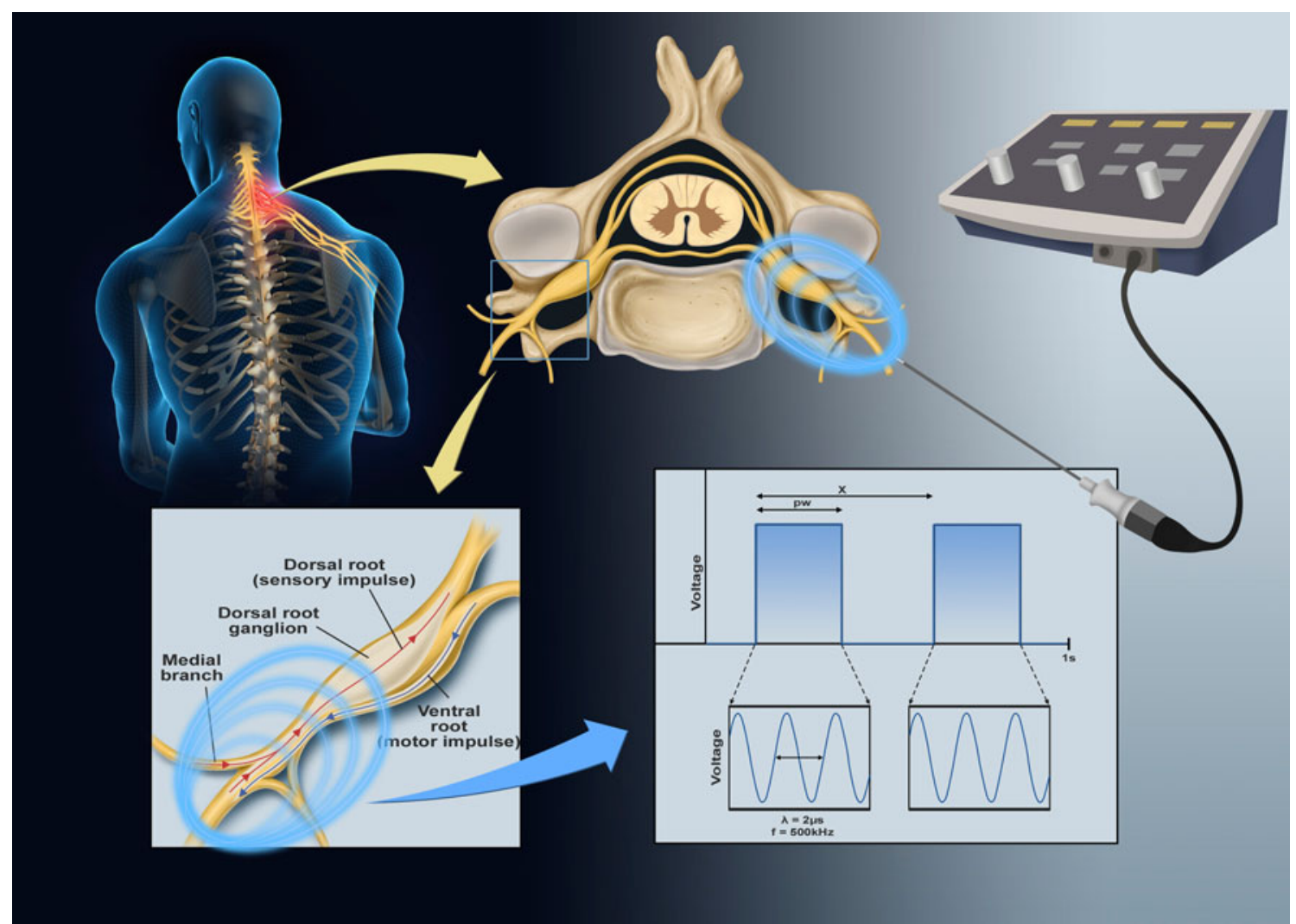

Fig. 1 Components of a PRF current in $1 \mathrm{~s}$. $\boldsymbol{\lambda}$ wavelength of intrinsic RF current; $\boldsymbol{f}$ frequency of intrinsic RF current at usually $500 \mathrm{kHz}$; $\boldsymbol{p} \boldsymbol{w}$ pulse width; $x$ duration of each pulse cycle and therefore Pulse Frequency $=1 / x$

they induce. This electric field can be represented simply by Maxwell's equation:

$E=\frac{j}{\sigma}$

Where $\mathrm{E}$ is the electric field vector around the electrode placed, $\mathrm{j}$ is the current density vector, and $\sigma$ is the specific electrical conductivity of the tissue.
The induced transmembrane potentials can result in tissue disruption that could, in fact, be even more specific than that caused by heat. These effects occur at subcellular and biomolecular levels without substantially elevated temperatures. Ion channels disruption, resting, and threshold potentials alterations are all possible effects. The transmembrane potential generated is proportional to the electric field strength, and this can be represented as:

Transmembrane Potential $\alpha \frac{\text { Amplitude of Electric Field applied } \times \text { Radius of target nerve }}{\text { Frequency of intrinsic RF waves }}$

The high transmembrane potentials $\left(\mathrm{U}_{\mathrm{m}}\right.$ of $\left.0.1-1 \mathrm{~V}\right)$ can cause electroporation which is the process of deformation, pores creation, and if high enough, the rupture of the cell membranes [14, 67].

Lower electric field phenomena, which are the leading explanation for PRF effects, may theoretically result in longterm depression (LTD), as possible sequelae of conditioning stimulation $[14,53]$. In that view, the low frequency of pulses and the high voltages in PRF induces LTD of synaptic transmission at the spinal cord, and in so doing, antagonizes the long-term potentiation that is purported to underlie many chronic pain states $[39,41]$. This, however, does not explain for the observed effects of PRF in applications where there is no nervous tissue anywhere near the electrode tip, such as in intra-articular PRF [3, 52].

\section{Biologic effects}

In an animal study evaluating the histologic effects of continuous $\mathrm{RF}$ at $67^{\circ} \mathrm{C}$ and PRF applied adjacent to rabbit dorsal root ganglia (DRG), Erdine et al. [19] found mitochondrial degeneration and a loss of nuclear membrane 
integrity in the continuous, but not in the PRF group. Another histopathologic study [42], comparing the effects of continuous RF and PRF delivered at $42^{\circ} \mathrm{C}$ on the rat DRG and sciatic nerve, showed no structural changes aside from transient endoneurial edema and collagen deposition. More recent studies on ultrastructural axonal changes showed microscopic damage after PRF exposure, abnormal membranes and morphology of mitochondria, and disruption and disorganization of microfilaments and microtubules [17]. Another similar study showed that most of the damaged myelinated axons showed only separation in myelin configuration after PRF for $120 \mathrm{~s}$. In addition, newly formed myelinated axons were also observed in this group [59]. These histological findings are believed to be a result of the high transmembrane potentials generated with tissues exposed to the electrical fields during PRF application.

We highlight two extremely informative in vivo studies. At first, Ozsoylar et al. [59] found that by applying PRF to the rear paw of rats after tight ligation of the L5 and L6 spinal nerves, mechanical allodynia was significantly reduced. In another study, Aksu et al. [2] evaluated the effects of PRF after tight ligation of the sciatic nerve in rabbits. In the treatment group, operated animals received 8 min of PRF applied to the L5 and L6 DRG 10 days after nerve injury. There were two control groups: one in which the injured animals received no current through the electrode; another in which a sham operation was done, and the skin closed without ligating the sciatic nerve. In this elegantly designed experiment, it was demonstrated that: (1) animals who received operations experienced heat and mechanical hyperalgesia before treatment; (2) no significant changes in heat latency, or withdrawal thresholds were noted in those who underwent the sham operation; and (3) mechanical and thermal hyperalgesia returned to baseline after 4 weeks in those animals that underwent PRF, whereas they remained the same in the sham PRF-operated group. These findings suggest that PRF treatment adjacent to the dorsal root may actually alleviate neuropathic pain.

In summary, based on electric field strength calculations, in vitro observations of heat spikes and early ultrastructural changes from histologic studies, it seems certain that PRF does produce definite tissue changes. These biological changes do translate into in vivo findings that can reduce or alleviate iatrogenically induced neuropathic pain in animal models.

\section{Methods}

In order to further evaluate the clinical efficacy of PRF, a systematic search for clinical studies on PRF was carried out. We searched the MEDLINE (PubMed) and EMBASE database, using the free text terms: PRF, RF, radiation, isothermal radiofrequency, and combination of these. We classified the information according to the type of study reported in two tables, one focusing only on RCTs (Table 1), and another containing prospective studies (Table 2). We did not analyze reports dealing with only conventional RF techniques. Date of last electronic search was 30 May 2010.

\section{Available evidence}

We found six RCTs that evaluated the efficacy of PRF, one against corticosteroid injection, one against sham intervention, and the rest against conventional RF thermocoagulation. Two trials were conducted in patients with lower back pain due to lumbar zygapophyseal joint pain, one in cervical radicular pain, one in lumbosacral radicular pain, one in TN, and another in chronic shoulder pain (details of trials are presented in Table 1). The methodological quality of the presented reports was scored using the original criteria proposed by Jadad et al. [30]

\section{Cervical radicular pain}

Radiofrequency treatment, adjacent to the cervical DRG, was first described by van Kleef et al. [62, 63], but there were reported side effects of transient neuritis and a loss of muscle strength in the hand. Due to the side effects and the possibility of deafferentation pain, PRF to the cervical DRG grew in popularity. We found only one randomized trial of PRF treatment for cervical radicular pain, with a Jadad's score of 5. Van Zundert et al. [65] reported that the effect of PRF group compared to sham at 3 months showed a significantly better outcome with regards to the global perceived effect ( $>50 \%$ improvement) and visual analogue scale (20-point pain reduction). This translated to a NNT of 1.1 in the PRF group compared with NNT of 3 in the sham group. Six months after the procedures, the NNT of PRF was 1.6 and 6 for the sham intervention.

Lumbar zygapophyseal joint pain

There were two randomized trials on low back pain that compared PRF treatment not against sham intervention but with RF denervation of the facet joints. Tekin et al. [57], with a Jadad score of 4 , showed that both treatment options have comparable results at 6 months, but the reduced pain scores were maintained at 1 year only for the RF group. However, Kroll et al. [32] showed that there was no significant difference between the RF and PRF groups in relative improvements in either pain scores (VAS) or disability (OWS Oswestry Low Back Pain and Disability Score) scores. Within the RF group, however, the VAS and 
Table 1 Randomized controlled trials (RCTs) on pulsed radiofrequency application (PRF)

\begin{tabular}{|c|c|c|c|c|c|}
\hline RCT & Condition & Groups & $\begin{array}{l}\text { Follow-up } \\
\text { (months) }\end{array}$ & Outcome & $\begin{array}{l}\text { Jadad } \\
\text { score } \\
{[30]}\end{array}$ \\
\hline $\begin{array}{l}\text { Eyigor } 2010 \\
{[20]}\end{array}$ & $\begin{array}{l}\text { Chronic } \\
\text { shoulder } \\
\text { pain }\end{array}$ & $\begin{array}{l}\text { PRF } \\
\text { suprascapular } \\
\text { nerve } n=25 \\
\text { Intra-articular } \\
\text { corticosteroid } \\
n=25\end{array}$ & 3 & $\begin{array}{l}\text { Within each group, improvements in VAS, } \\
\text { ROM (active and passive), and SPADI scores } \\
\text { were found in weeks } 1,4 \text {, and } 12 \text { compared to } \\
\text { pretreatment levels. No difference in the } 2 \text { groups } \\
\text { except for lower night pain at } 12 \text { weeks in the } \\
\text { corticosteroid group. }\end{array}$ & 4 \\
\hline $\begin{array}{l}\text { Kroll } 2008 \\
{[32]}\end{array}$ & $\begin{array}{l}\text { Lumbar facet } \\
\text { pain }\end{array}$ & $\begin{array}{l}\text { RF facet } n=13 \\
\text { PRF facet } n=13\end{array}$ & 3 & $\begin{array}{l}\text { No significant differences in relative improvement } \\
\text { were noted between groups in either VAS or OSW scores. } \\
\text { In CRF group but not for PRF group, VAS, and OSW } \\
\text { scores showed significant improvements over the 3-month interval. }\end{array}$ & 2 \\
\hline $\begin{array}{r}\text { Simopoulos } \\
2008[49]\end{array}$ & $\begin{array}{l}\text { Lumbrosacral } \\
\text { radicular pain }\end{array}$ & $\begin{array}{l}\text { PRF } n=37 \\
\text { PRF }+ \text { RF } n=39\end{array}$ & 2 & $\begin{array}{l}\text { There was no significant difference success response } \\
\text { rate or in the average decline in VAS between the } \\
2 \text { groups. Steep loss of analgesic effect between } \\
2-4 \text { months and return of baseline pain intensity by } \\
8 \text { months in both groups. No neurological deficits } \\
\text { were found in either group. }\end{array}$ & 1 \\
\hline $\begin{array}{l}\text { Tekin } 2007 \\
{[57]}\end{array}$ & $\begin{array}{l}\text { Low back pain } \\
\text { (facet pain) }\end{array}$ & $\begin{array}{l}\text { RF facet } n=20 \\
\text { PRF facet } n=20\end{array}$ & 12 & $\begin{array}{l}\text { At } 6 \text { and } 12 \text { months, RF group (not PRF group) } \\
\text { showed decrease in the VAS score and ODI. }\end{array}$ & 4 \\
\hline $\begin{array}{l}\text { Van Zundert } \\
2007[65]\end{array}$ & $\begin{array}{l}\text { Cervical } \\
\text { radicular pain }\end{array}$ & $\begin{array}{l}\text { PRF DRG } n=11 \\
\text { Sham } n=12\end{array}$ & 6 & $\begin{array}{l}\text { At } 3 \text { months, the PRF group showed a significantly xbetter GPE } \\
\text { ( }>50 \% \text { improvement) and VAS scores (20-point pain reduction). }\end{array}$ & 5 \\
\hline $\begin{array}{l}\text { Erdine } 2006 \\
{[18]}\end{array}$ & $\begin{array}{l}\text { Idiopathic } \\
\text { trigeminal } \\
\text { neuralgia }\end{array}$ & $\begin{array}{l}\text { RF Gasserian } \\
\text { ganglion } n=20 \\
\text { PRF Gasserian } \\
\text { ganglion } n=20\end{array}$ & 3 & $\begin{array}{l}\text { At } 3 \text { months, median VAS for RF group } \\
0.5(0-2) \text { and PRF group } 8.5(7-10) \text {. } \\
\text { Only } 2 \text { of } 20 \text { patients from the PRF group } \\
\text { had significant pain relief after procedure. }\end{array}$ & 4 \\
\hline
\end{tabular}

$R F$ conventional radiofrequency thermocoagualtion; $V A S$ visual analogue scale; $G P E$ global perceived effect; $O S W$ Oswestry low back pain and disability score; SPDI shoulder pain and disability index

OWS scores showed significant improvement over the 3month interval. This was not the case for the PRF group. In this study, however, there was no description of the blinding process, nor was there an account of the patients who withdrew or were lost to follow-up.

\section{Lumbosacral radicular pain}

We included the study by Simopoulos et al. [49], in view of its pilot nature, despite an absence of a blinding process in the study design. Patients with lumbosacral radicular pain were randomized into two groups. One group was treated with PRF only, while the second group was treated first with PRF and then with RF to the maximum tolerated temperature. There was no significant difference in the percentage of successful response rate or in the average decline in VAS between the two groups. There were no neurological deficits, such as motor loss or dermatomal hyposensitivity in either of the two treatment groups. Survival curves showed that for both treatment groups there was a steep loss of analgesic effect between 2 and
4 months. By the eighth month, the vast majority of patients had returned to their baseline pain intensity [49].

\section{Trigeminal neuralgia}

A systematic review of ablative neurosurgical techniques for the treatment of $\mathrm{TN}$ evaluated 166 studies reporting on RF thermocoagulation, glycerol rhizolysis, balloon compression of the gasserian ganglion, and stereotactic radiosurgery, concluded that $\mathrm{RF}$ thermocoagulation offers the highest rates of complete pain relief [34]. PRF treatment, as a less neurodestructive modality, soon became more attractive due the possibilities of fewer complications. Case reports have generated mixed results [64]. An RCT by Erdine et al. [18] compared the efficacy of conventional RF treatment with PRF treatment of the trigeminal ganglion for patients suffering from idiopathic TN. Their results demonstrate significant pain reductions in all the patients treated with conventional RF, while only 2 of 20 patients in the PRF group experienced this level of pain relief. 
Chronic shoulder pain

Eyigor et al. [20], in a recent trial, compared intra-articular corticosteroid injection versus suprascapular nerve PRF in several aspects, including pain, shoulder disability, healthrelated quality of life (HRQoL), and depression scores, as well as range of motion (ROM). Both groups demonstrated significant improvements up to 3 months in terms of pain scores, ROM, and HRQoL. Patients in the intra-articular corticosteroid injections were found to have improved pain scores and shoulder disability scores when compared to suprascapular nerve PRF. The efficacy of suprascapular nerve PRF of up to 6 months had also been reported in longitudinal studies [33].

\section{Observational studies}

In our modern evidence-based medicine era, RCTs have become the gold standard for assessing the effectiveness of therapeutic procedures. However, they can at times produce inconsistent results [28] and have limited external validity [43] due to the "rigid" settings in which the trial was conducted. Well-designed observational studies can contribute to the field of evidence-based pain medicine and often do not overestimate the magnitude of effects when compared to RCTs $[10,11]$. There are six prospective studies of the use of PRF in chronic pain management. These observational studies were listed according to indications and then sorted by year of publication in Table 2. In addition to the evidence presented in the trials, these longitudinal studies were conducted in conditions that included discogenic pain [56], chronic inguinal herniorrhaphy pain [45], chronic testicular pain [38], and sacroiliac joint pain [60]. They demonstrate the use of PRF in a variety of indications, and in some instances, showed positive results where conventional treatments have failed. These types of studies are, however, subjected to a great degree of publication bias.

\section{Discussion}

In addition to the histological and ultrastructural axonal findings in PRF, and the animal studies demonstrating PRF effects, there are also convincing biochemical basis for PRF effects. Higuchi et al. [27] demonstrated that pulsed but not continuous $\mathrm{RF}$ applied at $38^{\circ} \mathrm{C}$ to the rat cervical DRG resulted in increased c-Fos immunoreactivity in the laminae I $\&$ II of the dorsal horn $3 \mathrm{~h}$ after treatment. These effects were not seen in animals treated with continuous $\mathrm{RF}$ at $38^{\circ} \mathrm{C}$. Although not specific for nociceptive pathways, the expression of c-Fos is an indirect marker of neuronal activity as cFos is often expressed when neurons fire actions potentials $[5,50]$. Its presence indicates that nerve fibers have been activated by high electric fields, and that these changes are detectable up to the dorsal horn of the spinal cord. Lending further evidence to the definite biological effects of PRF, an upregulation of ATF-3 (activating transcription factor-3), another marker of "cellular stress" was observed in the DRG neuronal bodies in animal models with PRF applied to the L4 DRG compared to sham-operated and L4 axotomised controls [26]. In addition, Hagiwara et al. [24] more recently demonstrated that PRF may actually enhance the descending noradrenergic and serotonergic inhibitory pathways, which are intimately involved in the modulation of neuropathic pain. From the available evidence, PRF appears to have genuine

Table 2 Prospective studies on pulsed radiofrequency application (PRF)

\begin{tabular}{|c|c|c|c|c|c|}
\hline $\begin{array}{l}\text { Prospective } \\
\text { study }\end{array}$ & Condition & Intervention & $\begin{array}{l}\text { Diagnostic } \\
\text { block }\end{array}$ & Patients & Outcome \\
\hline $\begin{array}{l}\text { Liliang } \\
2009 \text { [33] }\end{array}$ & Chronic shoulder pain & PRF of suprascapular nerve & Yes & 11 & $\begin{array}{l}\text { Significant reductions in VAS } \\
\text { and SPDI scores at } 1 \& \\
6 \text { months }\end{array}$ \\
\hline $\begin{array}{l}\text { Misra } 2009 \\
{[38]}\end{array}$ & Chronic testicular pain & PRF of the spermatic cord & No & 10 & $\begin{array}{l}4 \text { complete pain relief; } 1 \\
\text { partial; } 1 \text { loss to follow-up }\end{array}$ \\
\hline $\begin{array}{l}\text { Vallejo } \\
2006[60]\end{array}$ & $\begin{array}{l}\text { Sacroiliac joint pain } \\
\text { syndrome (failed } \\
\text { conventional treatment) }\end{array}$ & $\begin{array}{l}\text { PRF of the medial branch of } \mathrm{L} 4 \text {, posterior } \\
\text { primary rami of L5, and lateral branches } \\
\text { S1 and S2 }\end{array}$ & No & 22 & $\begin{array}{l}16 \text { experienced } \geq 50 \% \text { pain } \\
\text { relief; } 12 \text { lasted } \geq 10 \text { weeks }\end{array}$ \\
\hline $\begin{array}{l}\text { Teixeira } \\
2006[56]\end{array}$ & Discogenic pain & Intra-discal $60 \mathrm{~V}$ PRF for $20 \mathrm{~min}$ & Discography & 8 & $\begin{array}{l}\text { Fall in NRS } \geq 4 \text { for all } \\
8 \text { patients at } 3 \text { months }\end{array}$ \\
\hline $\begin{array}{l}\text { Rozen } \\
2006[46]\end{array}$ & $\begin{array}{l}\text { Chronic inguinal } \\
\text { herniorrhaphy pain }\end{array}$ & T12, L1 and L2 nerve root PRF & Yes & 5 & $\begin{array}{l}\text { All } 5 \text { experienced } \geq 75 \% \text { pain } \\
\text { relief for } 6-9 \text { months }\end{array}$ \\
\hline $\begin{array}{l}\text { Mikeladze } \\
2003 \text { [37] }\end{array}$ & $\begin{array}{l}\text { Chronic zygapophyseal joint } \\
\text { pain (lumbar and cervical) }\end{array}$ & $\begin{array}{l}\text { Medial branch PRF of the zygapophyseal } \\
\text { joint }\end{array}$ & Yes & 114 & $\begin{array}{l}68 \text { patients experienced } \geq 50 \% \\
\text { pain relief for } \geq 3 \text { months }\end{array}$ \\
\hline
\end{tabular}

NRS numerical rating scale; SPDI: shoulder pain and disability index 
biological effects in cell morphology, synaptic transmission, and pain signaling, which are likely to be temperature independent.

Translated into patient management, some well-conducted trials have substantiated its use in conditions, such as cervical radicular pain [65]. In conditions whereby conventional RF had already been established as an effective treatment, such as in facet denervation, PRF would prove to be of little benefit. In fact, van Boxem et al. [61] estimate RF lesioning of the facet joint to be effective with a NNT between 1.1 and 1.5. In conditions where the efficacy of conventional RF had been demonstrated but with significant complications, such as in TN [31], and to a lesser extent, sphenopalatine ganglion treatment of cluster headaches [47], PRF application would appear to be attractive. The evidence at the current moment, however, does not support this. In our opinion, one of the main reasons for this is the insufficient "PRF dose" applied in some of the above-mentioned studies. In a recent study on the effects of PRF on Resiniferatoxin-induced neuropathic pain in an animal model, the anti-allodynic effects of PRF was significantly greater when PRF exposure was increased from 2 to $6 \mathrm{~min}$ [55]. This dose effect of PRF has not been evaluated formally in human studies.

As Cohen et al. [9] aptly put it, "PRF is a treatment in search for a cause". Even though more substantiated evidence is required, PRF has repeatedly been demonstrated to be a safe and effective procedure, even in instances where other treatment modalities have failed [25, 54]. Its use in a variety of conditions demonstrates the attractiveness of PRF as a less invasive alternative to surgical intervention that may involve significant morbidity.

There had also been some anecdotal reports and retrospective studies on the intra-articular application of PRF [25, 52]. Given the paucity of evidence for intraarticular PRF, we cannot even begin to imagine how this might work. The authors suggest that the current is actually deflected by the bony surfaces of the joint, forcing it to remain inside the joint space, and thus, resulting in a more localized effect [52]. There may, in fact, be a plausible explanation for this: Electric fields have demonstrated effects on immune modulation, as there are studies that show proinflammatory cytokines, such as interleukin (IL)$1 \mathrm{~b}$, TNFa and IL- 6 are attenuated by electric fields $[29,52]$. Upregulation of adenosine A2A receptor density has also been observed in human neutrophils treated with generated electric fields [66], and this appeared to be associated with inhibition of the catabolic cytokines, such as TNFa, IL-6, and IL-8 [4, 58]. Another hypothesis on the mode of action of intra-articular PRF is a possible cartilage-protective or regenerative mechanism. In vitro studies have demonstrated that chondrocyte proliferation and matrix synthesis were found to be significantly enhanced by electric field exposure $[15,16,22,40]$. Fini et al. [21] suggest that pulsed electric field delivery combines an anabolic effect on chondrocytes, a catabolic cytokine blockage, a stimulatory effect on anabolic cytokine production, and a counteraction of the inflammatory process in osteoarthritis. However, these effects are at the moment restricted to observations that will need to be reproduced in vivo [52] in a more systematic manner. Future research may involve changing our focus from pain transmission and neural tissue effects, and broaden the evaluation of PRF to different cell lines and tissue types.

\section{Conclusion}

From the available evidence, the use of PRF to the DRG in cervical radicular pain is compelling. With regards to its lumbosacral counterpart, the use of PRF cannot be similarly advocated in view of the methodological quality of the included study. PRF application to the supracapular nerve was found to be as efficacious as intra-articular corticosteroid in patients with chronic shoulder pain. The use of PRF in lumbar zygapophyseal joint pain and TN was found to be less effective than conventional RF thermocoagulation techniques. The included studies in the latter two conditions were unfortunately not powered to detect a difference in heatrelated complications. Review of prospective longitudinal studies draw the conclusion that PRF exhibits a high safety margin in a myriad of conditions including discogenic pain, chronic inguinal herniorrhaphy pain, and chronic testicular pain. Its efficacy, however, needs to be verified against identical control subjects. There also exist unanswered questions regarding the effective "PRF dose" based on voltage settings and duration of PRF treatment which require further clinical studies in order to substantiate.

\section{Conflicts of interest None.}

Open Access This article is distributed under the terms of the Creative Commons Attribution Noncommercial License which permits any noncommercial use, distribution, and reproduction in any medium, provided the original author(s) and source are credited.

\section{References}

1. Ahadian FM (2004) Pulsed radiofrequency neurotomy: advances in pain medicine. Curr Pain Headache Rep 8(1):34-40

2. Aksu R, Ugur F, Bicer C, Menku A, Guler G, Madenoglu H, Canpolat DG, Boyaci A (2010) The efficiency of pulsed radiofrequency application on L5 and 16 dorsal roots in rabbits developing neuropathic pain. Reg Anesth Pain Med 35(1):11-15

3. Al-Badawi EA, Mehta N, Forgione AG, Lobo SL, Zawawi KH (2004) Efficacy of pulsed radio frequency energy therapy in temporomandibular joint pain and dysfunction. Cranio 22(1):10-20 
4. Benton HP, MacDonald MH, Tesch AM (2002) Effects of adenosine on bacterial lipopolysaccharide- and interleukin 1induced nitric oxide release from equine articular chondrocytes. Am J Vet Res 63(2):204-210

5. Bogduk N (2006) Pulsed radiofrequency. Pain Med 7(5):396-407

6. Byrd D, Mackey S (2008) Pulsed radiofrequency for chronic pain. Curr Pain Headache Rep 12(1):37-41

7. Cahana A (2005) Pulsed radiofrequency: a neurobiologic and clinical reality. Anesthesiology 103(6):1311, author reply 1313-4

8. Cahana A, Van Zundert J, Macrea L, van Kleef M, Sluijter M (2006) Pulsed radiofrequency: current clinical and biological literature available. Pain Med 7(5):411-423

9. Cohen SP, Van Zundert J (2010) Pulsed radiofrequency: rebel without cause. Reg Anesth Pain Med 35(1):8-10

10. Concato J, Horwitz RI (2004) Beyond randomised versus observational studies. Lancet 363(9422):1660-1661

11. Concato J, Shah N, Horwitz RI (2000) Randomized, controlled trials, observational studies, and the hierarchy of research designs. N Engl J Med 342(25):1887-1892

12. Cornelissen P, van Kleef M, Mekhail N, Day M, van Zundert J (2009) Evidence-based interventional pain medicine according to clinical diagnoses. 3. Persistent idiopathic facial pain. Pain Pract 9(6):443-448

13. Cosman ER (2005) A comment on the history of the pulsed radiofrequency technique for pain therapy. Anesthesiology 103 (6):1312, author reply $1313-4$

14. Cosman ER Jr, Cosman ER Sr (2005) Electric and thermal field effects in tissue around radiofrequency electrodes. Pain Med 6(6):405-424

15. De Mattei M, Caruso A, Pezzetti F, Pellati A, Stabellini G, Sollazzo V, Traina GC (2001) Effects of pulsed electromagnetic fields on human articular chondrocyte proliferation. Connect Tissue Res 42(4):269-279

16. De Mattei M, Pasello M, Pellati A, Stabellini G, Massari L, Gemmati D, Caruso A (2003) Effects of electromagnetic fields on proteoglycan metabolism of bovine articular cartilage explants. Connect Tissue Res 44(3-4):154-159

17. Erdine S, Bilir A, Cosman ER, Cosman ER Jr (2009) Ultrastructural changes in axons following exposure to pulsed radiofrequency fields. Pain Pract 9(6):407-417

18. Erdine S, Ozyalcin NS, Cimen A, Celik M, Talu GK, Disci R (2007) Comparison of pulsed radiofrequency with conventional radiofrequency in the treatment of idiopathic trigeminal neuralgia. Eur J Pain 11(3):309-313

19. Erdine S, Yucel A, Cimen A, Aydin S, Sav A, Bilir A (2005) Effects of pulsed versus conventional radiofrequency current on rabbit dorsal root ganglion morphology. Eur J Pain 9(3):251-256

20. Eyigor C, Eyigor S, Korkmaz OK, Uyar M (2010) Intra-articular corticosteroid injections versus pulsed radiofrequency in painful shoulder: a prospective, randomized, single-blinded study. Clin J Pain 26(5):386-392

21. Fini M, Giavaresi G, Carpi A, Nicolini A, Setti S, Giardino R (2005) Effects of pulsed electromagnetic fields on articular hyaline cartilage: review of experimental and clinical studies. Biomed Pharmacother 59(7):388-394

22. Fioravanti A, Nerucci F, Collodel G, Markoll R, Marcolongo R (2002) Biochemical and morphological study of human articular chondrocytes cultivated in the presence of pulsed signal therapy. Ann Rheum Dis 61(11):1032-1033

23. Gallagher RM (2006) Pulsed radiofrequency treatment: what is the evidence of its effectiveness and should it be used in clinical practice? Pain Med 7(5):408-410

24. Hagiwara S, Iwasaka H, Takeshima N, Noguchi T (2009) Mechanisms of analgesic action of pulsed radiofrequency on adjuvant-induced pain in the rat: roles of descending adrenergic and serotonergic systems. Eur J Pain 13(3):249-252

25. Halim W, Chua NH, Vissers KC (2010) Long-term pain relief in patients with cervicogenic headaches after pulsed radiofrequency application into the lateral atlantoaxial (C1-2) joint using an anterolateral approach. Pain Pract. Epub

26. Hamann W, Abou-Sherif S, Thompson S, Hall S (2006) Pulsed radiofrequency applied to dorsal root ganglia causes a selective increase in ATF3 in small neurons. Eur J Pain 10(2):171-176

27. Higuchi Y, Nashold BS Jr, Sluijter M, Cosman E, Pearlstein RD (2002) Exposure of the dorsal root ganglion in rats to pulsed radiofrequency currents activates dorsal horn lamina I and II neurons. Neurosurgery 50(4):850-855, discussion 856

28. Horwitz RI (1987) Complexity and contradiction in clinical trial research. Am J Med 82(3):498-510

29. Igarashi A, Kikuchi S, Konno S (2007) Correlation between inflammatory cytokines released from the lumbar facet joint tissue and symptoms in degenerative lumbar spinal disorders. J Orthop Sci 12(2):154-160

30. Jadad AR, Moore RA, Carroll D, Jenkinson C, Reynolds DJ, Gavaghan DJ, McQuay HJ (1996) Assessing the quality of reports of randomized clinical trials: is blinding necessary? Control Clin Trials 17(1):1-12

31. Kanpolat Y, Savas A, Bekar A, Berk C (2001) Percutaneous controlled radiofrequency trigeminal rhizotomy for the treatment of idiopathic trigeminal neuralgia: 25-year experience with 1,600 patients. Neurosurgery 48(3):524-532, discussion 532-4

32. Kroll HR, Kim D, Danic MJ, Sankey SS, Gariwala M, Brown M (2008) A randomized, double-blind, prospective study comparing the efficacy of continuous versus pulsed radiofrequency in the treatment of lumbar facet syndrome. J Clin Anesth 20(7):534-537

33. Liliang PC, Lu K, Liang CL, Tsai YD, Hsieh CH, Chen HJ (2009) Pulsed radiofrequency lesioning of the suprascapular nerve for chronic shoulder pain: a preliminary report. Pain Med 10(1):70-75

34. Lopez BC, Hamlyn PJ, Zakrzewska JM (2004) Systematic review of ablative neurosurgical techniques for the treatment of trigeminal neuralgia. Neurosurgery 54(4):973-982, discussion 982-3

35. Malik K, Benzon HT (2007) Pulsed radiofrequency: a critical review of its efficacy. Anaesth Intensive Care 35(6):863-873

36. Malik K, Benzon HT (2008) Radiofrequency applications to dorsal root ganglia: a literature review. Anesthesiology 109 (3):527-542

37. Mikeladze G, Espinal R, Finnegan R, Routon J, Martin D (2003) Pulsed radiofrequency application in treatment of chronic zygapophyseal joint pain. Spine J 3(5):360-362

38. Misra S, Ward S, Coker C (2009) Pulsed radiofrequency for chronic testicular pain-a preliminary report. Pain Med 10(4):673-678

39. Munglani R (1999) The longer term effect of pulsed radiofrequency for neuropathic pain. Pain 80(1-2):437-439

40. Pezzetti F, De Mattei M, Caruso A, Cadossi R, Zucchini P, Carinci F, Traina GC, Sollazzo V (1999) Effects of pulsed electromagnetic fields on human chondrocytes: an in vitro study. Calcif Tissue Int 65(5):396-401

41. Pockett S (1995) Spinal cord synaptic plasticity and chronic pain. Anesth Analg 80(1):173-179

42. Podhajsky RJ, Sekiguchi Y, Kikuchi S, Myers RR (2005) The histologic effects of pulsed and continuous radiofrequency lesions at 42 degrees $\mathrm{C}$ to rat dorsal root ganglion and sciatic nerve. Spine (Phila Pa 1976) 30(9):1008-1013

43. Rabeneck L, Viscoli CM, Horwitz RI (1992) Problems in the conduct and analysis of randomized clinical trials. Are we getting the right answers to the wrong questions? Arch Intern Med 152(3):507-512

44. Racz GB, Ruiz-Lopez R (2006) Radiofrequency procedures. Pain Pract 6(1):46-50

45. Rozen D, Ahn J (2006) Pulsed radiofrequency for the treatment of ilioinguinal neuralgia after inguinal herniorrhaphy. Mt Sinai J Med 73(4):716-718

46. Rozen D, Parvez U (2006) Pulsed radiofrequency of lumbar nerve roots for treatment of chronic inguinal herniorraphy pain. Pain Physician 9(2):153-156 
47. Sanders M, Zuurmond WW (1997) Efficacy of sphenopalatine ganglion blockade in 66 patients suffering from cluster headache: a 12- to 70-month follow-up evaluation. J Neurosurg 87(6):876880

48. Shah RV, Ericksen JJ, Lacerte M (2003) Interventions in chronic pain management. 2. New frontiers: invasive nonsurgical interventions. Arch Phys Med Rehabil 84(3 Suppl 1):S39-S44

49. Simopoulos TT, Kraemer J, Nagda JV, Aner M, Bajwa ZH (2008) Response to pulsed and continuous radiofrequency lesioning of the dorsal root ganglion and segmental nerves in patients with chronic lumbar radicular pain. Pain Physician 11(2):137-144

50. Sluijter ME (2001) Pulsed radiofrequency. In Radiofrequency, part 1. Fliovopress SA, Meggen (LU), Switzerland. p. 55-68 (186)

51. Sluijter ME (2005) Pulsed radiofrequency. Anesthesiology 103 (6): 1313 , author reply $1313-4$

52. Sluijter ME, Teixeira A, Serra V, Balogh S, Schianchi P (2008) Intra-articular application of pulsed radiofrequency for arthrogenic pain-report of six cases. Pain Pract 8(1):57-61

53. Sluijter ME, van Kleef M (2007) Pulsed radiofrequency. Pain Med 8(4):388-389, author reply 390-1

54. Snidvongs S, Mehta V (2010) Pulsed radio frequency: a nonneurodestructive therapy in pain management. Curr Opin in Support Palliat Care 4(2):107-110

55. Tanaka N, Yamaga M, Tateyama S, Uno T, Tsuneyoshi I, Takasaki M (2010) The effect of pulsed radiofrequency current on mechanical allodynia induced with resiniferatoxin in rats. Anesth Analg 111(3):784-790

56. Teixeira A, Sluijter ME (2006) Intradiscal high-voltage, longduration pulsed radiofrequency for discogenic pain: a preliminary report. Pain Med 7(5):424-428

57. Tekin I, Mirzai H, Ok G, Erbuyun K, Vatansever D (2007) A comparison of conventional and pulsed radiofrequency denervation in the treatment of chronic facet joint pain. Clin J Pain 23 (6):524-529

58. Tesch AM, MacDonald MH, Kollias-Baker C, Benton HP (2002) Chondrocytes respond to adenosine via A(2)receptors and activity is potentiated by an adenosine deaminase inhibitor and a phosphodiesterase inhibitor. Osteoarthritis Cartilage 10(1):34-43

59. Tun K, Cemil B, Gurcay AG, Kaptanoglu E, Sargon MF, Tekdemir I, Comert A, Kanpolat Y (2009) Ultrastructural evaluation of Pulsed Radiofrequency and Conventional Radiofrequency lesions in rat sciatic nerve. Surg Neurol 72(5):496-500, discussion 501

60. Vallejo R, Benyamin RM, Kramer J, Stanton G, Joseph NJ (2006) Pulsed radiofrequency denervation for the treatment of sacroiliac joint syndrome. Pain Med 7(5):429-434

61. van Boxem K, van Eerd M, Brinkhuizen T, Patijn J, van Kleef M, van Zundert J (2008) Radiofrequency and pulsed radiofrequency treatment of chronic pain syndromes: the available evidence. Pain Pract 8(5):385-393

62. van Kleef M, Liem L, Lousberg R, Barendse G, Kessels F, Sluijter M (1996) Radiofrequency lesion adjacent to the dorsal root ganglion for cervicobrachial pain: a prospective double blind randomized study. Neurosurgery 38(6):1127-1131, discussion 1131-2

63. van Kleef M, Spaans F, Dingemans W, Barendse GA, Floor E, Sluijter ME (1993) Effects and side effects of a percutaneous thermal lesion of the dorsal root ganglion in patients with cervical pain syndrome. Pain 52(1):49-53

64. Van Zundert J, Brabant S, Van de Kelft E, Vercruyssen A, Van Buyten JP (2003) Pulsed radiofrequency treatment of the Gasserian ganglion in patients with idiopathic trigeminal neuralgia. Pain 104(3):449-452

65. Van Zundert J, Patijn J, Kessels A, Lame I, van Suijlekom H, van Kleef M (2007) Pulsed radiofrequency adjacent to the cervical dorsal root ganglion in chronic cervical radicular pain: a double blind sham controlled randomized clinical trial. Pain 127(1-2):173-182

66. Varani K, Gessi S, Merighi S, Iannotta V, Cattabriga E, Spisani S, Cadossi R, Borea PA (2002) Effect of low frequency electromagnetic fields on A2A adenosine receptors in human neutrophils. $\mathrm{Br}$ J Pharmacol 136(1):57-66

67. Weaver JC (1993) Electroporation: a general phenomenon for manipulating cells and tissues. J Cell Biochem 51(4):426-435 